\title{
Erratum to: Comparative lung bioavailability of fluticasone/salmeterol via a breath-actuated spacer and conventional plastic spacers
}

\author{
Arun Nair ${ }^{1} \cdot$ Lorna McKinlay ${ }^{1} \cdot$ Peter Williamson $^{1}$. \\ Philip Short $^{1} \cdot$ Patricia Burns $^{1} \cdot$ Brian J. Lipworth ${ }^{1}$
}

Published online: 26 April 2017

(C) Springer-Verlag Berlin Heidelberg 2017

Erratum to: Eur J Clin Pharmacol (2011) 67:355-363

DOI 10.1007/s00228-010-0989-9

The following note was unfortunately omitted from the original version of this article: Clinical Trials.gov NCT01194700.

The online version of the original article can be found at doi:http://dx.doi. org/10.1007/s00228-010-0989-9

\footnotetext{
Brian J. Lipworth

brianlipworth@googlemail.com

Arun Nair

a.nair@dundee.ac.uk

1 Asthma \& Allergy Research Group, Division of Medical Sciences, Ninewells Hospital \& Medical School, University of Dundee,

Dundee, Scotland DD1 9SY
} 